UDC 330.341:631.1

http://doi.org/10.21272/mmi.2019.1-16

JEL Classification: Q10, Q13, Q16

Ogundare Jeremiah Ayodele,

Ahmadu Bello University, Nigeria

Idachaba Odekina Innocent,

Ahmadu Bello University, Nigeria

Sule Jaafaru Garba,

Ph.D., Kogi State University, Nigeria

\title{
INNOVATION AS A MEDIATING OF RELATIONSHIP BETWEEN INTERNAL AND EXTERNAL ENVIRONMENT IN AGRIBUSINESS PERFORMANCE
}

Abstract. Agriculture plays an important role in our daily lives and that is why the agroindustry is seen as an engine in determining the social, political and economic development of the country. Therefore, this paper seeks to examine innovation as a mediating of the relationship between internal and external environment on agribusiness performance that is operating in Osun State Nigeria. The main purpose of the paper is to find out if innovation mediates between the internal and external environment. The specific objective of this study is to find out if competitive intensity and technology have an effect on agribusiness performance. The study makes a significant contribution by adding a mediating variable to the two-independent variable. The study used competitive intensity as a variable of internal environment and technology as a variable for the external environment. The study looks at four sub-activities of agribusiness in Osun State which are crop production, livestock, forestry and fishing. The study uses knowledgebased theory as a suitable theory that links the independent variable to the dependent variable. The study looks at the direct relationship of the independent variable to the dependent variable as well as the indirect relationship this time adding the mediating variable. The study retrieves data from owners/managers of the business. The study makes used of questionnaires using stratified sampling. 80 questionnaires were distributed to owners/managers of agribusiness in Osun State out of which, 72 questionnaires were retrieved from owners/managers of the agribusiness. Data were analysed using structural equation modelling processed on smartp/3. The findings show that the intensity of the competition has a negative and insignificant effect on the productivity of the agribusiness, while technology has a positive and significant impact on the productivity of the agribusiness. The research also establishes that innovation is an intermediary between technology and agribusiness performance, while innovation does not mediate between the competitive intensity and the performance of agribusiness. The study concludes that innovation only mediates the interconnection between the external environment and the performance of agribusiness. Therefore, the research recommended that managers/owners of the agribusiness pay less attention to the internal environment, since this has no influence on productivity, while a lot of attention has to be paid to the external environment.

Keywords: agribusiness, competitive intensity, innovation, performance and technology.

Introduction. For many years, the Nigerian government has been reforming agriculture through negligence, thereby diversifying it is economy's oil dependence. As a result, many companies, individuals and donors now want to invest in Nigeria's agriculture again. However, agriculture is regarded as a business that can provide a reasonable basis for the export of agricultural products for export to earn further wealth, job creation and the country's potential.

Agriculture has an important role to play in our daily lives and is an important ingredient in successful developing country organizations. Agribusiness is considering an engine in determining the social, political and economic development of a country (Gavrea et al., 2011). In other words, action in the agricultural industry is considered to produce suitable new foods, high-quality foods for the Nationwide market and to serve the export market successfully to serve foreign currency. Agricultural activities in the Osun State consist of four sub-activities, namely: Plant production; Cattle; stomach; and fishing. Growth in the sector is driven by Crop Production output. Holistic agricultural policy of the government of Osun sometimes in

Cite as: Ayodele, O. J., Innocent, I. O., \& Garba, S. J. (2019). Innovation as a Mediating of Relationship Between Internal and External Environment in Agribusiness Performance. Marketing and Management of Innovations, 1, 196-207. http://doi.org/10.21272/mmi.2019.1-16 
2011 placed the state on the green map in the southwestern country within 6 years, making it one of the largest suppliers of agricultural products to markets in Lagos and other southwestern states. The government has made great profits in the value chain evolution by exporting 50,000 tons of cocoa every year, building $700 \mathrm{~km}$ of rural roads and building bridges to reduce the cost of transport for peasants and increase market access and give more than 2.8 billion dollars to peasants like loans. (Vanguard Newspaper, 2017/03/13).

Baloyi (2010) considered that, despite the existence of agri-food companies, their actions have become worrying as enterprises in the country continue to weaken (not all agricultural sectors grow). Studies show that $90 \%$ of enterprises do not start to function after the third anniversary due to a lack of environmental factors (Douglas, Micah and Tom 2014). Moreover, there are other companies that have stagnated during the survival phase that this may be due to poor performance (Bidzakin, 2009). The project, as an organization's ability to achieve an adjustment as a high yield, is a quality product; A big market, good financial results and survival at a given time using a meaningful strategy for action. Thus, the operation can also be used to reflect on how the organization performs the market, the range of products, customer issues, loyalty and investment (Obiwuru et al., 2011). That's why Wang (2010) watched the performance, such as product performance, focus on results and achievements in the organization. Organizational activity can be achieved if such an organization has a favourable business environment.

However, according to Ancona et al., (2001), it states that the business environment and the sustainability of organizations are innovation. This creative ability eventually leads to an organization aimed at sustainable competitiveness and becomes an important step towards achieving a high level of performance in a positive environment. In addition, Calantone et al., (2002) have a great deal of responsive impact on external and external environments and thus effectively achieve competitive competitiveness.

A business environment is marked by different dynamic features such as global competition, informational technology, cultural factors and corporate social responsibility, which requires administrators to rethink and reappear their access to various operations and this business environment is classified in the internal and external environment (Lutheran, 2007). The internal environment is that environment with key internal aspects that must be aligned within an organization for improved efficiency or effective change (Waterman et al., 1980). During the outer environment, this environment is one of the factors that influence companies from outside (Alkali and Abu, 2012, Pearce and Robinson, 2007).

Greve (2007) has highlighted the innovation that enables the organization to access resources to adapt to a willing environment. According to Albury (2005) looks at the requirements of successful innovation to create new processes, product updates and services and effective methods. This innovative process, if appropriate with the organization and with a favourable business environment can lead to the activities of the companies. Nigeria still accounts for about $\$ 3$ to $\$ 5$ billion import in a year, especially in wheat, rice, fish and various articles, including fresh fruits. As a result, Nigeria is not safe food. The levels of shortage remain high in product areas, reducing the supply of foods to processing factories requiring them to conserve importation of supplies. Nigeria faces two blocks in agriculture today: the inability to meet domestic foods and the inability to export at the quality and quantity of levels required for market success (Report of the Federal Ministry of Agriculture and Rural Development FMARD, 2016).

Despite the large concentration of agricultural research institutes, a large quantity of climate conditions suitable for cultivating crops with landmass measuring 27,249 square kilometres to sustain cultivation of crops such as maize, yam, cashew, rice, plants, cocoa, raw products, cashews, soya beans, leafy vegetables among others the State is not sufficient in food sufficient and still depends on the output of other states (FMARD, 2016). However, the performance of agribusiness in Osun State has declined despite the government intervention, the supply of rice in 2015 was 2.6 million tons and later reduced to 2.3 million tons with a high demand of 6.3 million as at 2016. Also, the supply of maize, tomato, cocoa and 
cotton in 2015 was 7.2 million tons, 0.10 million tons, 0.30 million tons, 0.6 million tons and later reduce to 7.0 million tons, 0.8 million tons, 0.25 million tons and 0.2 million tons with a high demand of 7.5 million tons, 2.2 million tons, 3.6 million tons and 0.7 million tons respectively in 2016. (FMARD report, 2016).

The important role of innovation in the relationship between the internal and external business environment for the growth and survival of agribusinesses in Nigeria is the key parameter. Therefore, it is important to study the level of innovation that enhances the relationship between the internal and external business environment for the performance of agribusiness. There are many different studies on the effectiveness of internal and external business environments for empirical performance, but so far, the results have yielded unconvincing and conflicting results and studies. Research has failed to innovate between the relationship between the internal and external business environment on the performance of agribusiness. Therefore, this study tends to look at innovation as a mediating of the relationship between internal and external business environment on Agribusiness in Osun State using competitive intensity and technology as a measure of both internal and external business environment.

Literature Review. KBT emphasizes information as the most important thing in corporate sources (Grant, 1996). Kirsimarja and Aino (n.d) reported that the organizations did differently because of their diversity of knowledge stocks and the ability to use and develop information. The authors continue to clarify that organizations exist to create, transmit, and convert information into competitive work. Information is related to people. Individuals are interested and intelligent. In complex cases that no one else can understand, Krismarmarja and Aino (n) admit that there is a need for integration and information cohesion. More info will be deleted and submitted. The independent variables in the study are always used by organisations to gather knowledge for the use of organisations. Competitive intensity is used by an organization's management to gather information for superiority over other surrounding business organizations. While Technology is used to gather information about new technologies in the environment and how the organization can be innovative. The KBT preaches that this knowledge can lead to organizational performance (Grant, 1996). Poyhonen (2005) argued that the sources of information would lead to the innovation and innovation of the organizations and that the institutions would perform effectively. According to Poyhonen (2005), information will ultimately lead to improvements that will lead to performance. This thus explains that innovation can act as a mediator between competitive intensity and technology. Both competitive intensity and technology can be said to be knowledge resources, as they are used to gather information.

The concept of Agribusiness Performance. There is no universally acceptable performance definition, but two definitions have been taken into account for the purpose of this study. Muda et al., (2014) describe the performance as one of the factors that can be assessed by the level of productivity, which includes the quality, quantity, knowledge or creativity of the individual in accordance with the responsibilities achieved in a certain period of time. On the other hand, Armstrong (2009) summarizes the performance from the output, product quality, efficiency, cost management, safety and health, employee relationships and development.

The concept of Internal Environment. An organization's internal environment includes the company's business status, finances, material resources, personnel and management skills, operating system and control system, stakeholder interests, policies and practices. procedures. Williams (2009) argues that the internal environment of an organization includes business-related factors that influence its ability to achieve set objectives, develop and implement a viable plan, and thereby contribute to its performance. While the operationalization of the internal environment of an organization remains varied, the specialists agree that the internal environment is a determining factor of the performance of an organization. Internal environmental forces provide strengths and weaknesses to the company (Tolbert and Hall, 2009). For the purposes of this study, competitive intensity is used to measure the internal environment of firms. Competitive intensity is one of the measures of the internal environment that includes product features, 
promotional strategies among competitors, access to distribution channels, customer service strategies and product diversity. The competitive intensity of the internal environment plays the most important role in determining the direction and unique qualities that define it from others and contributes to the formation of the internal environment of an organization providing an enabling environment for the organization to achieve its objectives (Oluwadare and Oni, 2016).

The concept of External Business Environment. The external environment of an enterprise is defined as consisting of such factors that affect its activities from the outside. These include economic dynamics, government policy, political atmosphere, social and cultural values, and technological dynamics Alkali and Abu (2012); Pearce and Robinson (2007) and Beal (2000). However, Ehlers and Lazenby (2011) point out that the external environment represents environmental variables that have a direct or indirect influence on the performance of an organization. In addition, Ojeda et al., (2007), the external environment consists of the macro-environment and the micro-environment, both of which have an impact on business performance. In this case, the macro environment includes socio-cultural, political, technological, demographic and economic factors, while the micro-environment is directly linked to the enterprise and affects the enterprise, made up of suppliers, customers and government institutions. and competitors. For the purposes of this study, technology is used as a measure of the external business environment.

Technology Environment. Small. Scale Entrepreneurs find it difficult to gaining access to technology which limits innovation and business competitiveness (Kayanula and Quartey, 2000). According to McNamara and Watson (2005), technology can be defined in accordance with all the techniques, such as the knowledge, techniques, resources, and equipment used to achieve the functions of others. the enterprise to incorporate practical practices, work patterns, and structures. The equipment and the means, but not the primary purpose, or the product to be followed. Technology has the potential to improve speed, quality and efficiency.

The concept of Innovation. Different authors defined innovation differently based upon concept and importance. Such as innovation is an idea, a product, or process, system or device that is perceived to be new to an individual, a group of people or firms, an industrial sector or society in general (Rogers, 1995). Innovation can be in the form of new product/service, the latest technology of production, the latest procedure for operation or latest managerial strategy to run the business (Liao, Fei and Liu, 2008). Also, innovation creates something new with value addition (Jacobs and Snijder, 2008). Schumpeter, (1928) in his research conceptualizes innovation as the instability of capitalism and pointed out, that innovation is a source of capitalist development.

Review of Literature. Oluwadare and Oni (2016) examine the effect of internal environment on the performance of small and medium scale enterprise in Kano metropolis. The study selects 85 specimens for research purposes. The research was based on the Slovenian formula used to determine the minimum sample size. The conclusions are based on the results of the analysis of the opinions of respondents for this research. The research is, however, recommended for exposure to statistical analysis. Shiamwama et al., (2014) examined the internal factors affecting the performance of businesses of retirees in Kakamega Municipality. The results show that key factors affect the performance of retired companies in the stability of the financial, physical and mental strengths, entrepreneurs and family members who are aware of the potential failure of the financial institutions and communications of the largest companies in Kakamega municipality. Yu and Zhang (2010) examined internal factors affecting the organizational internationalization process: Evidence from the Huawei case study. The result of the study illustrates the relationship of some organizational internal factors and the firm's internationalization. Hove and Tarisai (2013) examined the internal factors affecting the successful growth and survival of small and micro agri-business firms in Alice Communal Area. The result of the study is expressed in policy makers (government and public companies), SMEs and other researchers. Olatunji (2015) investigated the impact of information communication technology on small and medium scale enterprise productivity in Nigeria. 

Environment in Agribusiness Performance

The study investigates the effects of (ICT) information communication technology on (SME) productivity of small and medium enterprises in Nigeria. A survey-research approach of the data collection was adapted to 80 respondents. Therefore, the study described that stakeholders in small and medium-sized companies agree that the introduction of information communication technology in its activities changes its processes and productivity, which in turn increases profitability. The study found that the use of information communication technology by small and medium-sized scale companies opens new opportunities, reduces inventories and makes their services more marketable. The study recommended putting emphasis on modern technology, practical technological and entrepreneurial studies aimed at producing entrepreneurs. Mai and Phuong (2013) examined the impact of external environment, technology and innovation capacities, and leadership development on organizational performance in the food industry a qualitative study of food enterprises in Ho Chi Minh City, Vietnam. The study examines the current problems for implementing technology transfer and innovation processes at food processing companies in Ho Chi Minh City, Vietnam. The research carries out a comprehensive qualitative study consisting of eight in-depth interviews with Executive Managers and Research and Development managers; The study identifies seven main themes that emerged from the data related to the specific content for food processing companies. The correspondents of the study described how the relative problems of externals; Capabilities, leadership in their organizations contribute to technology transfer and innovation effectiveness, and in turn, lead to sustainable performance. In addition, the study respondents also identified the challenges associated with implementing technology transfer projects. Based on previous studies and challenges, the study proposes a conceptual model of the innovation process and technology transfer in food processing companies that have influenced three major factors: external environment, technology transfer and innovation capacities and leadership. Changes in one of these three factors may influence both the transfer of technology and the effectiveness of the innovation and the overall performance of the organization (Figure 1).

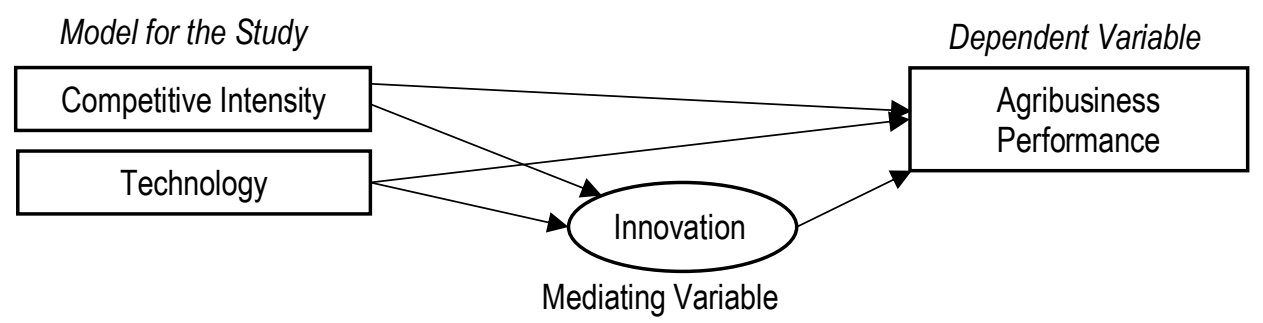

Sources: developed by the authors.

Figure 1. Model of the Study

Based on the literature overview and theoretical framework that links the independent variable to the intermediary variable and the dependent variable. The research, therefore, presupposes the variable as:

$\mathrm{H}_{1}$ Competitive Intensity has a significant effect on the performance of agribusiness in Osun State.

$\mathrm{H}_{2}$ Technology has a significant effect on the performance of agribusiness in Osun State.

$\mathrm{H}_{3}$ Innovation mediates the relationship between competitive intensity and performance of agribusiness in Osun State.

$\mathrm{H}_{4}$ Innovation mediates the relationship between technology and performance of agribusiness in Osun State.

Methodology. This study adopts a cross-sectional survey design. It was adopted because it is applicable to obtain relevant information about the current state of affairs (William, Brown and Onsman, 2010). The population of the study cannot be determined at the time the study was performed. Eighty (80) 

Environment in Agribusiness Performance

copies of questionnaires were distributed among the three senatorial districts in Osun State. The stratified and simple random technique was used to distribute copies of a questionnaire to the three senatorial districts in namely; Osun Central, Osun West and Osun East. The study involved a cross-section of businesses in the four sub-activities.

Data were obtained through the use of self-administered questionnaires to respondents. Questionnaires employed for this study were adapted from several authors. Competitive intensity questionnaire was adapted from Rivard, Raymond and Verreault (2006) with 5 items, technology questionnaire was adapted from the work of Akrofi, (2016) with 5 items, innovation questionnaire was adapted from Hughes and Mogan, (2007) with 3 items. While performance questionnaire was adapted from the work of Anastasia, (2008) with 6 items.

The study uses Partial Least Square (SmartPLS3) to analyze data and followed the two-stage approach for assessing the measurement model and the structural model respectively. According to the suggestions of Urbach and Ahlemann (2010). This study tested the important criteria and processes to estimate the outer and inner model. There are four common criteria to assess the outer model as following: Unidimensionality, reliability, convergent validity and discriminant validity. The second stage was used to assess the Goodness-of-fit and research hypotheses in the proposed research framework. The criteria to assess the outer model are as follows; coefficient of determination (R-Square, R2), path coefficient, and effect size (f2).

Results. To determine the reliability and validity of the tools used for data collection, the measurement model was calculated using PLS-SEM path modelling. Table 1 shows the reliability and validity of the latent variables of the study.

Table 1. Construct Reliability and Validity (Measurement Model) $n=72$

\begin{tabular}{|c|c|c|c|c|}
\hline Construct & Items & Loadings & AVE & $\mathrm{CR}$ \\
\hline \multirow{3}{*}{ Firm Performance } & FP1 & 0.80 & 0.65 & 0.85 \\
\hline & FP2 & 0.84 & & \\
\hline & FP3 & 0.77 & & \\
\hline \multirow{4}{*}{ Competitive Intensity } & CPI1 & 0.77 & 0.57 & 0.85 \\
\hline & $\mathrm{CPI} 2$ & 0.84 & & \\
\hline & CPI4 & 0.67 & & \\
\hline & CPI5 & 0.77 & & \\
\hline \multirow{2}{*}{ Innovation } & INV1 & 0.96 & 0.93 & 0.96 \\
\hline & INV2 & 0.97 & & \\
\hline \multirow{3}{*}{ Technology } & TGY1 & 0.79 & 0.57 & 0.80 \\
\hline & TGY3 & 0.74 & & \\
\hline & TGY4 & 0.75 & & \\
\hline
\end{tabular}

Note: AVE represents Average Variance Extracted; CR represents Composite Reliability. FP4, FP5, FP6, CPI3, INV3, TGY2, TGY5 were deleted because of their insufficient loadings.

Sources: developed by the authors.

Table 1 shows the reliability and validity of research designs. Structural reliability and convergence probability of structures were tested using composite reliability and extracted with the mean deviation (AVE), as proposed by Garson (2016). The combined reliability factor should also be $\geq 0.7$ (Lee and Chen, 2013), while the AVE should be $\geq 0.5$ (Garson, 2016). The load on the element should be higher than 0.5 . Table 1 shows that all positions corresponded to the minimum score for taxes (ie 0.5 ), the reliability of the composite (ie 0.7) and AVE (ie 0.5). It is therefore assumed that the elements in Table 1 show the reliability and convergent validity. The data were then subjected to a discriminant validity test using the FornellLarckercriterion. The result is presented in Table 2. 
O. J. Ayodele, I. O. Innocent, S. J. Garba. Innovation as a Mediating of Relationship Between Internal and External Environment in Agribusiness Performance

Table 2. Discriminant Validity using Fornell-Larcker Criterion $(\mathrm{n}=72)$

\begin{tabular}{|l|c|c|c|c|c|}
\hline & & $\mathbf{1}$ & $\mathbf{2}$ & $\mathbf{3}$ & $\mathbf{4}$ \\
\hline 1 & Competitive Intensity & $\mathbf{0 . 7 6}$ & & & \\
\hline 2 & Innovation & 0.32 & $\mathbf{0 . 9 6}$ & & \\
\hline 3 & Firm Performance & 0.24 & 0.52 & $\mathbf{0 . 8 0}$ & \\
\hline 4 & Technology & 0.31 & 0.63 & 0.46 & $\mathbf{0 . 7 6}$ \\
\hline
\end{tabular}

Note: The bolded numbers represent the square root of the AVE of each latent construct.

Sources: developed by the authors.

AVE was used in the study to establish discriminatory validity using the Fornell-Larker criterion. For the existence of discriminating reality, the square root of AVE should be higher than its correlation with other latent variables (Garson, 2016). In Table 2, the bold figures represent the square root of the AVE of each concealed design. The square root of AVE of each design is higher than their ratio with another latent construction. According to the Fornel-Larker criterion, the data revealed discriminatory validity. In the next study, the hypothesis of the study was tested by calculating the structural model, loading samples 5000 times.

Table 3. Direct Path Coefficient

\begin{tabular}{|c|c|c|c|c|c|}
\hline Relationship & Beta Coefficient & SE & T statistics & P Value & Decision \\
\hline CPI -> FP & 0.14 & 0.18 & 0.76 & 0.44 & Not Supported \\
\hline TGY ->FP & 0.41 & 0.10 & $3.98^{* * *}$ & 0.00 & Supported \\
\hline R Square & 0.23 & & & & \\
\hline
\end{tabular}

Note: CPI represents Competitive Intensity; TGY represents Technology; FP represents Firm Performance.

Sources: developed by the authors.

Table 3 provides information about the hypothesis test. One of the two formulated hypotheses was supported and the other was not supported. Table 3 shows that the intensity of competition does not affect the performance of the company and is signed by more than $10 \%(\beta=0.14, p<0.44)$. That is, an increase in the unit of competitive intensity will reduce the productivity of the company by $44 \%$. The technology has a significant impact on the performance of the company and at a level of less than $1 \%(\beta=0.41, p<0.00)$.

Table 4. Effect Size of Exogenous Variables

\begin{tabular}{|c|c|c|}
\hline Construct & $\boldsymbol{f}^{\mathbf{2}}$ & Effect Size \\
\hline Competitive Intensity & 0.03 & Small \\
\hline Technology & 0.20 & Medium \\
\hline
\end{tabular}

Note: NA means Not Applicable.

Sources: developed by the authors.

The study further examined the size of the effect of exogenous variables on the endogenous variable

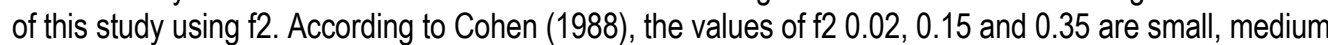
and large effects respectively. Table 4 shows the effect size of each of the exogenous variables in this study. The size of the impact of the competitive intensity on the firm's performance is 0.03 ; this means that competitive intensity has little effect on the firm's performance. The technology has a value of f2 0.20 , which means that the technology has a medium impact on the firm's performance.

The Q2 Stone-Gleisser value was used to predict the relevance of the model. The Q2 value of 0.02 is a small effect size, 0.15 is the average effect size and 0.35 represents a high effect size (Cohen, 1988). From Table 5 it is clear that the value Q2 of the performance of the company is higher than 0 . 
O. J. Ayodele, I. O. Innocent, S. J. Garba. Innovation as a Mediating of Relationship Between Internal and External Environment in Agribusiness Performance

Table 5. Construct Cross-validated Redundancy $\left(Q^{2}\right)$

\begin{tabular}{|c|c|c|c|}
\hline Construct & SSO & SSE & Q $^{2}$ (=1-SSE/SSO) \\
\hline Firm Performance & 216.000000 & 183.099718 & 0.15 \\
\hline
\end{tabular}

Sources: developed by the authors.

More precisely, Q2 is 0.15 ; this means that the independent variables of this study have an average degree of predictive relevance to the performance of the company.

Table 6. Structural Model for Indirect Effects

\begin{tabular}{|c|c|c|c|c|}
\hline Path $\boldsymbol{a}$ & Beta & Path $\boldsymbol{b}$ & Beta & Indirect Effects (a*b) \\
\hline CPI -> INV & 0.14 & INV -> PRF & 0.38 & 0.05 \\
\hline TGY -> INV & 0.59 & INV -> PRF & 0.38 & 0.22 \\
\hline
\end{tabular}

Sources: developed by the authors.

The effects of mediation can be determined by indirect effects (Hair et al., 2014). The value T is calculated as $a{ }^{*} b /$ SE (Hair et al., 2014). The value of T will be used in the study to determine the impact of innovation on the relationship between competitive intensity, technology and productivity. Table 7 shows the result of checking the significance of mediation relationships. Table 7 shows that innovation mediates the relationship between competitive intensity and productivity $(\beta=0.05, p<0.01)$. $\mathrm{H} 3$, which states that innovation mediates the relationship between competitive intention and performance, is therefore not supported.

Table 7. Structural Model: Test of Significance for Mediating Relationships

\begin{tabular}{|c|c|c|c|c|c|c|}
\hline Hypotheses & Relationship & Beta & SE & T Statistics & P Value & Decision \\
\hline $\mathrm{H}_{3}$ & CPI->INV->PRF & 0.05 & 0.09 & 0.55 & 0.00 & Not Supported \\
\hline $\mathrm{H}_{4}$ & TGY->INV->PRF & 0.22 & 0.08 & $2.75^{* *}$ & 0.38 & Supported \\
\hline
\end{tabular}

Note: ${ }^{* *} p<0.01 ;{ }^{* *} p<0.05 ;{ }^{*} p<0.1$.

Sources: developed by the authors.

Nevertheless, $\mathrm{H} 4$, which claims that innovation mediates the relationship between technology and productivity, is supported on the basis of Table $7(\beta=0.22, p>0.1)$. Only two of the four hypotheses that were formulated were empirically confirmed in this study. A summary of the hypothesis test is shown in Table 8.

Table 8. Summary of the Test of Hypotheses

\begin{tabular}{|c|c|c|c|c|}
\hline Hypotheses & Relationship & Beta & T Statistics & Decision \\
\hline $\mathrm{H}_{1}$ & CPI -> PRF & 0.18 & 0.76 & Not Supported \\
\hline $\mathrm{H}_{2}$ & TGY -> PRF & 0.10 & 3.98 & Supported \\
\hline $\mathrm{H}_{3}$ & CPI->INV->PRF & 0.05 & 0.55 & Not Supported \\
\hline $\mathrm{H}_{4}$ & TGY->INV->PRF & 0.22 & 2.75 & Supported \\
\hline
\end{tabular}

Sources: developed by the authors.

As can be seen in Table 9, the intensity of competition, technology and innovation account for $31 \%$ of productivity variations. This is considered appropriate because each R-square of more than $10 \%$ is considered appropriate in any management research. On the other hand, competitive intensity and technology account for $41 \%$ variance in innovation. 
O. J. Ayodele, I. O. Innocent, S. J. Garba. Innovation as a Mediating of Relationship Between Internal and External Environment in Agribusiness Performance

Table 9. R-Squared for Mediating Relationships

\begin{tabular}{|c|c|}
\hline Construct & R-Squared \\
\hline Performance & 0.31 \\
\hline Innovation & 0.41 \\
\hline
\end{tabular}

Sources: developed by the authors.

The effect size of each path in the full structural equation model was analysed in Table 10 using f2. The full size of the effect in Table 10 is to include innovation as an intermediate variable in the model of this study. Table 10 shows that competitiveness does not affect the performance of the company, but has a small impact on innovation. Technology has a small impact on productivity, but it has a major impact on innovation.

Table 10. Effect Size of Exogenous and Endogenous Variables

\begin{tabular}{|c|c|c|c|c|}
\hline Construct & $\boldsymbol{f}$ (PRF) & Effect Size & $\boldsymbol{f}($ INV) & Effect Size \\
\hline Competitive Intensity & 0.01 & None & 0.02 & Small \\
\hline Technology & 0.04 & Small & 0.53 & Large \\
\hline Innovation & 0.12 & Small & NA & NA \\
\hline
\end{tabular}

Note: NA represents Not Applicable.

Sources: developed by the authors.

Finally, innovation has little effect on the performance of the company. Q2 was used to predict the relevance of an internal model using the cross-checking of redundancy. Table 11 shows that productivity Q2 is 0.18 , which means that competitiveness, technology and innovation have an average predictive value.

Table 11. Construct Cross-validated Redundancy

\begin{tabular}{|c|c|c|c|}
\hline Construct & SSO & SSE & Q $^{2}$ (=1-SSE/SSO) \\
\hline Performance & 216.000000 & 176.531173 & 0.18 \\
\hline Innovation & 144.000000 & 89.115467 & 0.38 \\
\hline
\end{tabular}

Note: about performance. On the other hand, innovation has a value of $Q 2$ of 0.38 , which means that the competitiveness trio and technology have a high degree of predictive relevance for innovation.

Sources: developed by the authors.

It is important to estimate the extent of the mediating effect of innovation in the research model. For the purposes of this study, the dispersion that was taken into account (VAF) was used to assess the extent of the mediating effect of innovation on the relationship in this study. VAF is calculated by sharing indirect effects in general effects (Hair et al., 2014). As has been established, innovations largely mediate in the relationship between technology and productivity of the company. It is important to determine the extent of the mediating influence of innovation on the link between technology and productivity via VAF. Table 12 shows that innovation partially lays the link between technology and company performance based on the criteria of Hair's et al., (2014).

Table 12. The magnitude of the Mediating Effect

\begin{tabular}{|c|c|c|c|c|c|}
\hline Relationship & Indirect & Direct & Total & VAF & Mediation \\
\hline TGY->INV->PRF & 0.22 & 0.41 & 0.63 & $35 \%$ & Partial \\
\hline
\end{tabular}

Sources: developed by the authors. 
Based on the results of the study, the study showed that the intensity of the competition does not affect the productivity of the agribusiness and that technology has a significant impact on the productivity of the agribusiness. The research also showed that innovation only mediates the link between technology and agribusiness performance.

Conclusion. Previous studies largely ignored innovation and investigated the direct link between the internal and external environment, which are independent variables of this research on the performance of agribusiness, which is a dependent variable in this study. Despite the fact that academics advocate innovation as a mediating variable in the relationship between the competitive intensity (internal environment) of technology (external environment) and the productivity of agribusiness. To fill this gap in knowledge, this study has done empirical research into the mediating role of innovation in the relationship between competitive intensity and technology on the productivity of agribusiness. On the basis of empirical findings, the study concludes that innovation only mediates the connection between the external environment and the performance of the agribusiness, because the technology has a positive and significant impact on the performance of the agribusiness. Although innovation is not an intermediary between the domestic environment and the performance of agribusiness. Therefore, the research advised agribusiness managers/owners to pay a lot of attention to technologies (environment), and in others - to increase the productivity of agribusiness.

Authors Contributions. The conceptualizations of the variables were carried out by 0 . J. and I. I. Also, the methodology was carried out by $\mathrm{O}$. J. and I. I., while the original draft preparation was carried out by $\mathrm{O}$. J. Validation of the questionnaires used for the study was carried out by S. G.. Visualization of data was carried out by $\mathrm{O}$. J. and I. I., while the software used for the analysis was handled by $\mathrm{O}$. J. and I. I. Also, data analysis was carried out by 0 . J. and I. I., while writing, review and editing were carried out by O. J.

\section{References}

Akpor-Robaro, M. (2012) Impact of socio-cultural environment on entrepreneurial emergence: A theoretical analysis of Nigerian Society. European Journal of Business and Management Vol 4, 16:172-182.

Akrofi., A., E., (2016) Impact of external business environment factors on performance of small \& medium sized enterprises in the pharmaceutical industry in Kumasi Metropolis: A thesis submitted to department of marketing and corporate strategy Kwame Nkrumah University of science and technology school of business in partial fulfilment of the requirements for the degree of master of business administration strategic management \& consulting-option.

Albury, D. (2005). Fostering innovation in public services. Public money and management, 2511), 51-56.

Alkali. M., and Abu. H., (2012) Assessing the influence of external environmental factors, on the performance of small business manufacturing enterprises in Bauchi State, Nigeria. Interdisciplinary Journal of Contemporary Research in Business. Institute of Interdisciplinary Business Research Vol 4(7).

Anastasia, A. (2008). Measuring the impact of human resources management on organizational performance. University of Macedonia (GREECE). Journal of Industrial Engineering and Management01 (2): 119-142- ISSN: 2013-0853.

Ancona, D. G., Okhuysen, G. A., \& Perlow, L. A. (2001). Taking time to integrate temporal research. Academyof Management Review, 264), 512-529.

Apolot, S. (2012). Organizational learning, innovation and small and medium enterprise (SMEs) performance in Uganda: A research dissertation submitted to graduate and research centre in partial fulfilment of the requirements of the award of master of science in entrepreneurship and small business management of Makerere University.

Armstrong, M. (2009). Armstrong's handbook of human resource management practice. 11th edition. Kogan page. London and Philadelphia.

Azim, M. (2008). Socio-cultural environment for entrepreneurship development in Bangladesh. Journal of Bangladesh Studies 10(1), 51-60.

Baloyi, J. (2010).An Analysis of constraints facing smallholder farmers in the agribusiness value chain: A case of farmers in Limpopo Province. Master's thesis, Unpublished. University of Pretoria, Pretoria.

Beal, R. (2000). Competing effectively: Environmental scanning, competitive strategy, and organizational performance in small manufacturing firms. Journal of Small Business Management, 38(1), 27-47. 
Bidzakin, K. (2009). Assessing performance of micro and small scale agribusinesses in Northern Ghana: Non-financial and stochastic frontier analysis: a dissertation submitted to department of agricultural economics, agribusiness and extension, Kwame Nkrumah University of science and technology, in partial fulfilment of the requirements for the degree of master of science, agricultural economics.

Bojan, M., and Zoran, W., (2014). Analysis of external environments moderating role on the entrepreneurial orientation and business performance relationship among Italian small enterprises. International Journal of Trade Economic and Finance, Vol. 5(3).

Calantone, R. J., Cavusgil, S. T., \& Zhao, Y. (2002). Learning orientation, firm innovation capability, and firmperformance. Industrial marketing management, 31(6), 515-524. http://dx.doi.org/10.1016/S0019-8501(01)00203-6

Chidoko, C., Makuyana, G., Matungamire, P., \& Bemani, J., (2011). Impact of the informal sector on the current Zimbabwean economic environment. International Journal of Economics and Research. www.ijeronline.com.

Chin, W. W. (1998). The partial least squares approach for structural equation modeling. In Macoulides, G. A., ed. Modern methods for business research. Mahwah, $\mathrm{NJ}$ : Lawrence Erlbaum Associates.

Cohen, J. (1988). Statistical power analysis for the behavioral sciences (2nd ed.). New Jarsey: Lawrence Erlbaum Associates, Publishers. doi: $10.1234 / 12345678$

Douglas, N., Micah, O., \& Tom, M., (2014). Effect of internal control systems on financial performance of small and medium scale business enterprises in Kisumu City, Kenya. International Journal of Social Sciences and Entrepreneurship.Vol.1.

Dzisi, S., John-Engelbert, S., \& Ofosu, D., (2014). Globalization and SMEs in Ghana: effects, challenges and the way forward. Journal of Business and Enterprise Development, 4(1).

Ehlers, T., and Lazenby, K., (2011). Strategic management. South Africa concepts and cases. 3rd edition. Pretoria: Van Schaik enterprise (SMEs): A practical modified framework, World Journal of Social Sciences,1(3): 200212.

Enterprise Baseline Survey. (2012). Accessed on September 8, 2016 from www.sedinnigeria.net/images/documents/enterprise-baseline-survey-2012.pdf

Garson, D. (2016). Partial Least Squares: Regression \& Structural Equation Models. USA: Statistical Associates Publishing. Grant, R. M. (1996). Toward a knowledge-based theory of the firm. Strategic Management Journal, 17, 109-122.

Greve, H. R. (2007). Exploration and exploitation in product innovation. Industrial and Corporate Change, 16(5), 945-975.

Hair, J., Black, W., Babin, B., \& Anderson, R. (2014). Multivariate data analysis. $7^{\text {th }}$ edition pearson new international edition: UK. Hofstede, G. (1998). Identifying organizational subcultures: An empirical approach. Journal of Management Studies, 35(1), 1-12. Hughes, M and Mogan., R., E., (2007) Deconstructing the relationship between entrepreneur orientation and business performance at the embryonic stage of firm growth. Industrial marketing management 36(5) 651-661.

Ibrahim, A., and Goodwin, J., (1986). Perceived causes of success in small business. American Journal of Small Business, 11 (Fall), 41-50.

Iskandar, M., Ahmad, R., \& Martua, R., (2014). Factors influencing employee participation in a manufacturing company in the democratic Republic of Congo, Africa Journal of Business Management, 6(15), 5389-5398.

Isreal, G. (2013). Determining sample size, program evaluation and organizational development, University of Florida. PEOD6.ISSN: $2151-6219$

Jacobs, D., \& Snijders, H. (2008). Innovation routine: How managers can support repeated innovation? StichtingManagement Studies. Van Gorcum, Assen.

Kayanula, D., and Quartey, P., (2000). The Policy environment for promoting small and medium-sized enterprises in Ghana and Malawi, finance and development research programme, working paper series, paper No 15, IDPM, University of Manchester.

Kirsimarja, B., \& Aino, K. (n.d). Knowledge-based view of the firm - theoretical notions and implications for management. Retrieved from https://www.lut.fi/documents/10633/109602/tijo-valintakoeartikkeli-2015.pdf

Lee, K., \& Chen, S. (2013). Introduction to partial least square: Common criteria and practical considerations. Advanced Materials Research, 1766-1769.

Liao, S. H., Fei, W. C., \& Liu, C. T. (2008). Relationships between knowledge inertia, organizational learningand organization innovation. Technovation, 28(4), 183-195. http://dx.doi.org/10.1016/j.technovation. 2007.11.005

Mai, Q., and Phuong, V., (2013). The Impact of external environment, technology and innovation capacities, and leadership development on organizational performance in food industry. A qualitative study of food enterprises in Ho Chi Minh City, Vietnam. International Journal of Business, Humanities and Technology Vol. 3 No. 4.

McNamara, K., and Watson, G., (2005). The Development of a team-oriented structure in a small business enterprise. Journal of American Academy of Business. Cambridge Hollywood: Vol. 6, ISSN. 2, p, 184-190.

Obiwuru, T., Okwu, A., Akpa, V., \& Nwankwere, I., (2011). Effects of leadership style on organizational performance: A survey of selected (SSE) Lagos Nigeria, Australian Journal of Business and Management Research. 1(7): 100-111.

Ojeda, Julieta, \& Simpson. (2007). Achieving competitive advantage in the Mexican footwear industry. An International Journal. Vol. 14, No. 3, pp 289-305.

Olatunji, O. (2015). The Impact of information communication technology on small and medium scale enterprise productivity in Nigeria business economics and tourism.

Omolomo, Odunayo, \& Tobora. (2014). Challenges faced by entrepreneurs and the performance of small and medium scale (SMEs) in Nigeria. International Journal of Social and Humanistic Sciences. ISSN: 2300-2697, Vol. 42, pp. 32-40. 
O. J. Ayodele, I. O. Innocent, S. J. Garba. Innovation as a Mediating of Relationship Between Internal and External Environment in Agribusiness Performance

Pearce, A., and Robinson, B., (2007). Strategic management: Formulation, implementation and control (10 th $e$ dition). Boston: Irwin McGraw-Hill.

Poyhonen, A. (2005). Exploring the dynamic dimension of intellectual capital: renewal capability, knowledge assets and production of sustained competitive advantage. a paper presented at the 2005 PMA IC symposium: management and measurement of intangible assets and intellectual capital: multidisciplinary insights. New York, 15-16 December 2005.

Rivard, S., Raymond, L., and Verreault, D., (2006) Resource based view and competitive strategy; An integrated model of the contribution of information technology to firm performance.

Rogers, E. (1995). Diffusion of innovations. New York, NY: Free Press.

Rosli, M. (2011). Determinants of small and medium enterprises performance in the Malaysian auto part industry, Africa Journal of Enterprises Management, 5(20), 8235-8241.

Schumpeter, J. (1928). The Instability of capitalism. The Economic Journal, 38 (151), 361-386.

Shivani, S., Mukherjee, S., \& Sharan, R., (2006). Socio-cultural influences on Indian entrepreneurs: The need for appropriate structural interventions. Journal of Asian Economics, 17(1), 5-13.

Smedan and National Bureau of Statistic Collaborative Survey: Selected Findings (2013). Accessed September 8, 2016. From: http://nigerianstat. gov.ng/pdfuploads/SMEDAN\%202013_Selected\%20Tables.pdf

Urbach and ahleman (2010) structural equation modeling in information systems research using partial least square: journal of information technology theory and application hong kong vol. 11, iss. 2, pp 5-39.

Wang, X. (2010). Performance analysis for public and non- profit organizations. sudbury, mass.: Jones and Bartlett Publishers

William, B., Brown, T., \& Onsman, A. (2010). Exploratory factors analysis: A five-step guide for novies. Australasian Journal of Paramedicine, 8(3). Retrieved from http://ro.ecu.edu.au/jephc/vol8/iss3/1

Yeboah, M. (2014). Analysis of entrepreneurship: How does culture influence risk-taking in SMEs in the Sekondi-Takoradi Metropolis, Ghana. American International Journal of Contemporary Research. 4(2), 131-140.

о. й. Айоделе, Університет Ахмаду Белло (Нігерія);

I. О. Інносент, Університет Ахмаду Белло (Нігерія);

C. Й. Гарба, Рh.D., Державний університет Когі (Нiгерія).

Інновації як рушійна сила взаємодії внутрішнього та зовнішнього середовища функціонування агропромислового комплексу

Сільське господарство відіграє важливу роль у формуванні тенденцій соціального, політичного та економічного розвитку країни. У статті авторами висунуто гіпотезу, що інновації виступають рушійною силою взаємодії між внутрішніми та зовнішніми факторами розвитку агропромислових підприємств штату Осун, Нігерія. Авторами визначено вплив інтенсивності конкуренції та якості технологічного процес на ефективність діяльності агропромислових підприємств. Головною відмінністю даного дослідження $\epsilon$ побудова моделі взаємодії внутрішнього та зовнішнього середовища функціонування агропромислового комплексу з урахування фактору інновацій. У рамках дослідження автори приймають інтенсивність конкуренції за змінну внутрішнього середовища, тоді як технологічний процес виступає у якості зовнішньої змінної. У статті проаналізовано чотири галузі агропромислового комплексу штату Осун, які спеціалізуються на вирощуванні сільськогосподарських культур, тваринництві, лісопромисловості та рибальстві. Теоретичною основою даного дослідження $\epsilon$ наукові напрацювання вчених з досліджуваної тематики. Авторами визначено лінійну залежність незалежної змінної від залежної, а також нелінійний характер взаємозв'язку, у випадку додавання змінної - інновації. У ході дослідження було використано метод анкетування та опитано 80 респондентів - власників та керівників агропромислових підприємств штату Осун. 3 метою аналізу результатів опитування було використано систему структурних рівнянь та програмний комплекс smartp/3. Отримані результати дослідження свідчать про те, що підвищення інтенсивності конкуренції має негативний та статистично незначимий вплив на продуктивність агропромислового комплексу, тоді як вплив технологічного процесу $\epsilon$ позитивним та статистично значимим. Крім того, встановлено, що саме інновації сприяли встановленню позитивного та статистично значимого зв'язку між технологічним процесом та ефективністю діяльності агропромислових підприємств. На основі проведеного дослідження авторами запропоновано власникам/керівникам агропромислових підприємств особливу увагу звернути на заходи з підвищення ефективності комунікації з зовнішніми стейкхолдерами.

Ключові слова: агробізнес, інтенсивність конкуренції, інновації, інтенсивність, технологічний процес.

Manuscript received: 16.11.2018.

(c) The author(s) 2019. This article is published with open access at Sumy State University. 